\title{
MODEL PARTISIPASI MASYARAKAT DALAM PENENTUAN KEBIJAKAN PARIWISATA HALAL DI MADURA BERBASIS NILAI KEISLAMAN DAN HUKUM POSITIF
}

\author{
Achmad Badarus Syamsi, Adiyono \\ Fakultas Keislaman Universitas Trunojoyo Madura \\ Jl. Raya Telang PO BOX 2 Kamal Bangkalan \\ badarus.syamsi@trunojoyo.ac.id, readiyono13@gmail.com
}

\begin{abstract}
Madura Island has its own uniqueness from a socio-culture that breathes Islam. This is a positive value in dealing with halal tourism in the world. The fact that currently all districts in Madura have not welcomed halal tourism as a mainstay to increase the number of tourist visits both domestic and foreign. This can occur because public participation in policy making is still lacking or even non-existent. Because seeing the very strong diversity of the Madurese community with Islam, it is a must to implement a halal tourism policy. Public participation in drafting local regulations on tourism management in Madura can be seen in the FGD. This shows that the model of community participation in Madura is in accordance with a basic model of public participation, and a realism model of public participation. Meanwhile, based on Islamic values, the implementation of FGD can be included in the shura concept contained in Islam. The general public response wants the application of halal tourism on the island of Madura. But on the other hand they also emphasize the existence of halal tourism which actually implements tourism in accordance with the Shari'a.
\end{abstract}

Keywords: Community Participation, Halal Tourism, Islamic Values

Abstrak: Pulau Madura memiliki kekhasan tersendiri dari sosio-kultur yang
bernafaskan Islami. Hal tersebut merupakan nilai positif dalam menghadapi
pariwisata halal di dunia. Fakta yang ada sekarang ini semua kabupaten
yang ada di Madura belum menyambut pariwisata halal sebagai andalan
untuk meningkatkan jumlah kunjungan wisatawan baik nusantara maupun
mancanegara. Hal tersebut dapat terjadi karena partisipasi masyarakat dalam
pembentukan kebijakan masih kurang atau bahkan tidak ada. Dikarenakan
melihat keberagamaan masyarakat Madura yang sangat kuat dengan Islam 
merupakan suatu keharusan untuk menerapkan kebijakan pariwisata halal. Partisipasi masyarakat dalam penyusunan peraturan daerah tentang pengelolaan pariwisata di Madura dapat dilihat salah satunya dalam FGD. Hal itu menunjukkan bahwa model partisipasi masyarakat di Madura sesuai dengan model a basic model of public participation, dan a realism model of publik partisipation. Sementara berdasarkan nilai keislaman pelaksaan FGD bisa termasuk ke dalam konsep shura yang terdapat dalam Islam. Respons masyarakat secara umum menginginkan adanya penerapan halal tourism di pulau Madura. Namun di sisi lain mereka juga menekankan adanya halal tourism benar-benar menerapkan pariwisata yang sesuai dengan syariat.

Kata Kunci: Partisipasi Masyarakat, Pariwisata Halal, Nilai Keislaman

\section{A. Pendahuluan}

Pulau Madura merupakan sebuah pulau yang berada di Propinsi Jawa Timur. Terdapat empat kabupaten di pulau Madura, yaitu Bangkalan, Sampang, Pamekasan dan Sumenep. Tiap kabupaten mempunyai banyak sumber daya alam yang menjadi destinasi wisata. Kabupaten Bangkalan yang terletak paling barat pulau Madura memiliki objek wisata sebagai berikut: Pantai Rongkang, Pantai Maneron, Bukit Geger, Pantai Siring Kemuning, kolam renang galian C Jaddih Socah. ${ }^{1}$

Kabupaten Sampang yang berada di sebelah timur kabupaten Bangkalan mempunyai objek wisata antara lain: Wisata Pantai Camplong, Air Terjun Toroan, Hutan Kera Nipah, dan Pantai Lon Malang. ${ }^{2}$ Destinasi-destinasi wisata di kabupaten Pamekasan yaitu wisata api tak kunjung padam, air terjun Durbugen, pantai Jumiang, Rawa Mangunan, pantai Talang Siring, bukit Waru, gua Blaban. ${ }^{3}$ Kabupaten paling timur di pulau Madura yaitu kabupaten Sumenep mempunyai objek wisata sebagai berikut: pantai Slopeng, pantai Lombang, Gili Iyang, Gili Labak, pantai Badur. ${ }^{4}$

Selain banyak sumber daya alam yang berpotensi menjadi objek wisata utama seperti di atas, pulau Madura mempunyai masyarakat dan kebudayaannya yang unik dan khas. Pulau Madura merupakan sebuah pulau yang dihuni oleh suku Madura. Mayoritas penduduknya beragama Islam. Kebudayaan yang berbau keislaman sudah mengakar cukup dalam. Hal tersebut bisa dilihat dari antusiasme yang luar biasa dalam menyambut hari besar Islam. Selain itu jumlah pondok pesantren di Madura sangat banyak. Bahkan tokoh agama Islam mempunyai kedudukan yang sangat

1 http:/ / disbudpar.bangkalankab.go.id/app/\#, diakses pada tanggal 3 April 2019.

2 https://sampangkab.go.id/, diakses pada tanggal 3 April 2019.

3 http:// disparibud.pamekasankab.go.id/index.php/78-berita/109-tempat-wisata, diakses pada tanggal 3 April 2019 .

4 http://sumenepkab.go.id/wisata/baca/alam, diakses pada tanggal 3 April 2019. 
tinggi di pulau Madura. Terdapat istilah “bupak, babuh, guru, ratoh”, yang kemudian dijadikan konsep sebagai orang-orang yang paling dimuliakan oleh masyarakat Madura. Bupak dan babuh adalah bapak dan ibu biologis. Guru masudnya adalah Kyai, orang yang mengajarkan ilmu-ilmu agama Islam. Terakhir ratoh adalah pemimpin formal mulai dari kepala desa. ${ }^{5}$

Kultur keagamaan Islam yang kuat merupakan suatu kekhasan tersendiri yang dimiliki masyarakat Madura. Hal ini merupakan sebuah nilai yang sangat positif apabila dikaitkan dengan perkembangan dan kemajuan industri halal pada saat ini. Pada tahun 2019 Indonesia menjadi negara nomor 1 di dunia yang paling banyak dikunjungi oleh para wisatawan muslim dari seluruh penjuru dunia. ${ }^{6}$

Berdasarkan data di atas, konsep pariwisata halal sangat menarik dan urgent untuk diterapkan di pulau Madura. Selain itu hal senada juga disampaikan oleh Tuan Guru Bajang M. Zainul Majdi, gubernur tahun 2016 yang membuat peraturan pariwisata halal, bahwa kondisi di Madura hampir sama dengan di NTB banyak masyayikh atau kyai, sedangkan di NTB ada tuan guru. Menurut TGB terdapat beberapa langkah yang diperlukan agar pengelolaan pariwisata halal dapat berjalan dengan optimal. Pertama, visi pemangku jabatan yang berkomitmen dengan pariwisata halal. Kedua, regulasi yang mendukung atau mengatur pariwisata halal. Hal ini sangat penting karena berkaitan dengan budgeting policy (kebijakan penganggaran). Ketiga, adanya peran kalangan akademis dan pesantren untuk menjelaskan konsep pariwisata halal. ${ }^{7}$

Dari beberapa langkah atau poin yang disampaikan oleh TGB di atas, regulasi merupakan poin yang sangat vital dan menentukan. Selain berkaitan dengan budgeting policy, keberadaan regulasi akan menimbulkan kepastian hukum. ${ }^{8}$ Menurut Utrecht, kepastian hukum mengandung dua pengertian. Pertama, adanya regulasi membuat individu mengetahui perbuatan apa yang boleh atau tidak boleh dilakukan. Kedua, adanya keamanan hukum bagi individu dari kesewenangan pemerintah, karena dengan adanya regulasi itu individu dapat mengetahui apa saja yang boleh dibebankan atau dilakukan oleh negara terhadap individu. ${ }^{9}$ Para wisatawan dan investor baik mancanegara maupun nusantara akan mempertimbangkan adanya regulasi yang mengatur kepentingan mereka.

5 Mien A. Rifa’I, Manusia Madura: Pembawaan, Perilaku, Etos Kerja, Penampilan dan Pandangan Hidupnya Seperti Dicirakan Pribahasanya (Yogyakarta: Pilar Media, 2007), 57.

6 Global Muslim Travel Index (GMTI) report 2019, 21

7 Disampaikan pada seminar nasional dengan tema "Modernasi Pengembangan Pariwisata Halal" di Universitas Trunojoyo Madura pada tanggal 8 November 2018.

8 Peter Mahmud Marzuki, Pengantar Ilmu Hukum (Jakarta: Kencana, 2008), 158.

9 Riduan Syahrani, Rangkuman Intisari Ilmu Hukum, (Bandung: Penerbit Citra Aditya Bakti, 1999), hlm.23 
Sebuah regulasi atau peraturan dapat terbentuk salah satunya adanya masukan dari masyarakat. Ketentuan mengenai partisipasi masyarakat dalam pembentukan peraturan perundang-undangan diatur dalam bab XI Undang-undang Nomor 12 Tahun 2011 tentang Pembentukan Peraturan Perundang-undangan. Adapun model partisipasi masyarakat dalam pembentukan peraturan dapat dilakukan salah satunya dengan mengikutsertakan anggota masyarakat yang dianggap ahli dan independen dalam team atau kelompok kerja dalam penyusunan peraturan perundang-undangan. ${ }^{10}$

Penelitian ini urgen untuk dilakukan mengingat mayoritas masyarakat Madura beragama Islam. Masih banyak potensi wisata yang belum dikelola secara optimal. Sinergi dan harmonisasi untuk mengoptimalkan potensi sumber daya alam dengan konsep pariwisata syariah atau halal antara masyarakat pelaku pariwisata, tokoh agama dan pemangku kebijakan sangat diperlukan. Penerapan konsep pengelolaan pariwisata syariah atau halal di pulau Madura diharapkan dapat meningkatkan kunjungan wisatawan baik nusantara maupun mancanegara. Selain itu diharapkan juga berdampak pada peningkatan pendapatan dan pengurangan angka pengangguran di sekitar lokasi wisata.

Selain permasalahan regulasi, karena masyarakat Madura sangat kental keislamannya, maka yang urgent dibahas juga adalah model partisipasi masyarakat dalam penentuan kebijakan berbasis nilai-nilai keislaman. Hal ini menarik dan penting untuk mengetahui sinergitas dan konsistensi masyarakat Madura yang selama ini dikenal dengan masyarakat yang berkearifan lokal berdasar nilai-nilai keislaman.

Dari sisi akademis penelitian ini merupakan sesuatu yang baru dalam perspektif dua disiplin ilmu pengetahuan, yaitu hukum positif dan hukum bisnis syariah. Kombinasi antara keduanya diharapkan dapat berkontribusi pada pengayaan dan pembaruan materi pengetahuan kedua bidang.

Penelitian Achmad Badarus Syamsi dengan judul Analisa Potensi Pariwisata di Bangkalan yang sesuai dengan Syariah dalam Menunjang Jawa Timur sebagai Salah Satu Destinasi Pariwisata Syariah menyimpulkan bahwa objek-objek wisata yang ada di Kabupaten Bangkalan belum sesuai dengan prinsip-prinsip syariah dalam pengelolaan pariwisata. ${ }^{11}$

10 Laporan akhir "Pengkajian Hukum tentang Partisipasi Masyarakat dalam Penentuan Arah Kebijakan Prioritas Penyusunan Peraturan Perundang-Undangan", oleh Tim Pengkajian Hukum Pusat Penelitian dan Pengembangan Sistem Hukum Nasional Badan Pembinaan Hukum Nasional (BPHN) Kementerian Hukum dan Hak Asasi Manusia RI, 2014, 76

11 Achmad Badarus Syamsi, "Analisa Potensi Pariwisata di Bangkalan yang sesuai dengan Syariah dalam Menunjang Jawa Timur sebagai Salah Satu Destinasi Pariwisata Syariah”, Prosiding seminar nasional dan call papers "Integrasi Disiplin Ilmu Keislaman dalam Konteks Madura”, diselenggarakan oleh Fakultas Keislaman Universitas Trunojoyo pada tahun 2016. 
Penelitian Alfisah Nurhayati dengan judul Revisiting Pariwisata Madura; Studi Kebijakan Pembangunan Kepariwisataan Kabupaten Sampang menyimpulkan adanya disharmonisasi antara kebijakan kepariwisataan yang ada dengan nilai-nilai dalam masyarakat Sampang. ${ }^{12}$

Penelitian Teguh Hidayatul Rachmad dengan judul Strategi Branding Wisata Syariah Pulau Madura menyimpulkan bahwa strategi dalam membangun branding wisata syariah Madura haris diawali dengan public identity, yaitu dengan membedakan diri dengan kabupaten atau pulau yang lain. ${ }^{13}$

Penelitian Laurensius Arliman S. dengan judul Peran Investasi dalam Kebijakan Pembangunan Ekonomi Bidang Pariwisata di Provinsi Sumatera Barat menyimpulkan peranan investasi dalam pembangunan ekonomi di bidang pariwisata sangat penting, terutama untuk memudahkan pembangunan pariwisata di Sumatera Barat. Dukungan pemerintah terhadap pembangunan ekonomi di bidang pariwisata di Sumatera Barat ditandai dengan pembangunan infrastruktur pariwisata, pembangunan rel kereta api sebagai moda transportsai serta pemberian pinjaman dan dimudahkannya pemberian izin di dalam berinvestasi di Sumatera Barat oleh BKPM. ${ }^{14}$

Pada topik kajian pariwisata halal, peneliti-peneliti sebelumnya lebih banyak mengidentifikasi potensi dan strategi pemasaran objek wisata di Madura. Adapun yang terkait dengan topik kajian kebijakan pariwisata, peneliti-peneliti sebelumnya lebih banyak mengidentifikasi permasalahan dari sisi model pengelolaan yang tersurat dalam peraturan daerah. Beberapa peneliti memang membahas kebijakan daerah tentang pariwisata. Namun, tidak ada penelitian yang mengkaji model partisipasi masyarakat pariwisata halal di Madura berbasis nilai-nilai keislaman dan ius constitutum. Keterbaharuan (novelty) penelitian ini adalah mengidentifikasi model partisipasi masyarakat dalam penentuan kebijakan pariwisata halal di Madura berbasis nilai-nilai keislaman dan ius constitutum, sehingga diharapkan kedepannya dapat memberikan sebuah rumusan kebijakan pariwisata halal kepada pihak terkait yang sesuai dengan nilai-nilai keislaman dan ius constitutum atau hukum positif.

12 Alfisah Nurhayati, "Revisiting Pariwisata Madura; Studi Kebijakan Pembangunan Kepariwisataan Kabupaten Sampang”, Jurnal Karsa, Vol. XVIII Nomor 2. Oktober 2010.

13 Teguh Hidayatul Rachmad," Strategi Branding Wisata Syariah Pulau Madura”, Commed: Jurnal Komunikasi dan Media, Vol. 1 Nomor 2. Februari 2017.

14 Laurensius Arliman S.," Peran Investasi dalam Kebijakan Pembangunan Ekonomi Bidang Pariwisata di Provinsi Sumatera Barat”, Kanun: Jurnal Ilmu Hukum, Vol. 20 Nomor 2. Agustus 2018. 


\section{B. Metode Penelitian}

Penelitian ini adalah field research yang bersifat deskriptif kualitatif. Penelitian ini termasuk penelitian hukum empiris atau disebut juga penelitian hukum sosiologis (socio legal research) yang menitikberatkan terhadap kerjanya hukum di masyarakat, ${ }^{15}$ yaitu mengenai model partisipasi masyarakat dalam penentuan kebijakan pariwisata halal di Madura berbasis nilai-nilai keislaman dan ius constitutum. Pada penelitian ini, data primer diperoleh melalui pengisian kuisioner oleh responden secara langsung serta melalui hasil wawancara dengan responden untuk menunjang keakuratan data kuisioner, berikut adalah datanya : Stakeholder pariwisata, masyarakat yang terkait langsung dengan objek wisata. Misalnya pengelola objek wisata dan pengusaha tour dan travel. Para tokoh agama, pengurus MUI dan organisasi masyarakat keislaman, Pemangku jabatan, dinas pariwisata. Setelah data dikumpulkan kemudian diolah dan dianalisa dengan analisa kualitatif dengan logika induktif. Pola berpikir induktif ini untuk menganalisis data-data yang bersifat khusus untuk ditarik kepada yang umum, yaitu identifikasi peraturan daerah tentang pengelolaan pariwisata, model partisipasi masyarakat dalam penyusunan peraturan daerah tentang pengelolaan pariwisata di Madura dan respon masyarakat pelaku pariwisata dan tokoh agama terhadap ius constitutum peraturan daerah tentang pariwisata dan konsep pariwisata halal. Kemudian dari hasil analisa data yang diperoleh dideskripsikan secara urut dan teliti sesuai dengan permasalahan yang dikaji.

\section{Hasil dan Pembahasan}

\section{Model Partisipasi Masyarakat dalam Hukum Positif atau ius constitutum}

Secara bahasa kata partisipasi berarti perihal turut berperan serta, keikutsertaan, atau peran serta. ${ }^{16}$ Apabila dikaitkan dengan penyelenggaraan negara, partisipasi bisa diartikan sebagai bentuk keikutsertaan masyarakat dalam berbagai bentuk kegiatan penyelenggaraan negara. Proses pembuatan kebijakan, pelaksanaan kebijakan dan evaluasi terhadap pelaksaan sebuah kebijakan merupakan beberapa bentuk dari partisipasi masyarakat. Keberadaan partisipasi masyarakat akan sangat ditentukan oleh terlibat atau tidaknya masyarakat dalam kegiatan pemerintahan sebuah negara, khususnya dalam ranah legislatif. ${ }^{17}$

15 Bambang Sunggono, Metodologi Penelitian Hukum (Jakarta: PT Raja Grafindo Persada, 1998), 43.

16 Tim Redaksi Kamus Besar Bahasa Indonesia Edisi Ketiga, (Jakarta: Balai Pustaka, Departemen Pendidikan Nasional, 2005), 831.

17 Laporan akhir "Pengkajian Hukum tentang Partisipasi Masyarakat dalam Penentuan Arah Kebijakan Prioritas Penyusunan Peraturan Perundang-Undangan”.....15. 
Partisipasi dalam ilmu politik dibagi menjadi dua, yaitu partisipasi aktif dan partisipasi pasif. Partisipasi aktif dimanifestasikan dalam bentuk pengajuan usul suatu kebijakan, alternatif kebijakan dan kritik untuk memperbaiki dan meluruskan ius constitutum. Sedangkan partisipasi pasif dimanifestasikan dalam bentuk kegiatan menaati peraturan pemerintah serta menerima dan melaksanakan setiap keputusan pemerintah. ${ }^{18}$

Terkait partisipasi dalam pembentukan peraturan perundang-undangan, suatu kegiatan berupa Parliamentary Support Programme memetakan empat model partisipasi. Adapun dasar yang digunakan dalam memetakan model tersebut adalah model pilihan partisipasi sesuai dengan tingkat perkembangan politik suatu negara. ${ }^{19}$ Keempat model dimaksud adalah : pertama, partisipasi murni (pure representative democracy), dalam kondisi ini keterlibatan rakyat dalam suatu negara demokrasi dilakukan oleh wakil-wakil yang dipilih melalui pemilihan umum yang duduk di lembaga perwakilan. ${ }^{20}$

Pada model tersebut, masyarakat tidak terlibat langsung dalam proses pembentukan sebuah kebijakan, melainkan diwakilkan kepada wakil rakyat di lembaga perwakilan. Kedua, a basic model of public partisipation. Model ini agak lebih luas dibandingkan model pertama, dimana keterlibatan masyarakat tidak hanya pada saat mereka memilih wakilnya pada saat pemilihan umum, melainkan juga melakukan kontak dengan lembaga perwakilan. ${ }^{21}$ Pada model ini, keterlibatan dilakukan secara bebas, di mana siapapun bisa melakukan kontak, walaupun demikian, lembaga perwakilan belum membuka ruang dialog yang lebih luas bagi masyarakat. ${ }^{22}$

Ketiga, a realism model of publik partisipation. Pada model ini, publik selain ikut dalam pemilihan umum juga melakukan interaksi dengan lembaga perwakilan, tetapi interaksi tersebut telah dilakukan secara berkelompok. Di mana pelakupelaku partisipasi publik telah mengarah pada kelompok-kelompok kepentingan dan organisasi-organisasi yang sudah terorganisir. ${ }^{23}$

Keempat, model The Possible Ideal for South Africa. Model ini merupakan gabungan dari tiga model sebelumnya. Di mana, keterlibatan masyarakat dalam pemilihan umum, kontak dengan lembaga perwakilan maupun melalui organisasi atau kelompok dalam masyarakat dijadikan wahana untuk berpartisipasi. Konsep

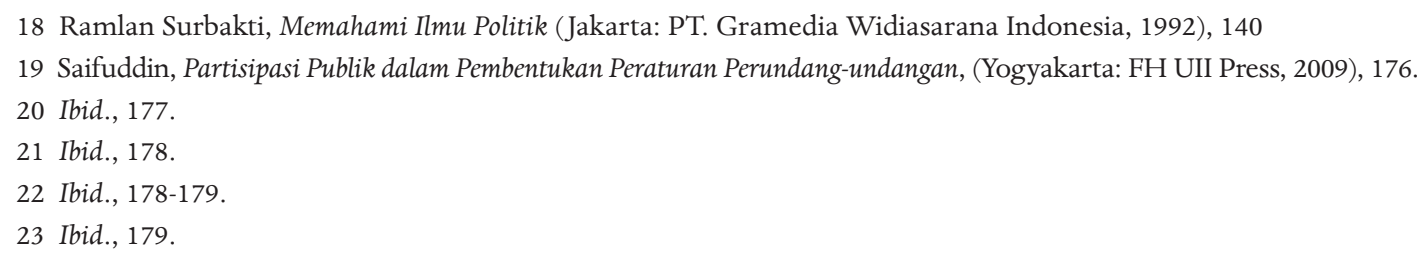


partisipasi yang hendak dibangun adalah keterlibatan dari berbagai kekuatan partisipan dalam proses pengambilan keputusan publik dan pembentukan undangundang. ${ }^{24}$

Pembentukan suatu undang-undang harus dapat dipertanggungjawabkan kepada publik agar melahirkan undang-undang yang baik. Pembentukan undangundang harus dilakukan secara transparans, partisipatif, dan akuntabel sehingga masyarakat dapat ikut mengawasi dan sekaligus memberikan masukan kepada pembentuk undangundang. Substansi suatu undang-undang berasal dari bawah (bottom up), bukan berasal dari atas (top down) yang selama ini terjadi untuk beberapa undang-undang. Jika substansi undang-undang bottom up maka diharapkan akan menghasilkan undangundang yang baik dan berkeadilan yang pada gilirannya akan mudah dipatuhi oleh masyarakat dan memberikan kepastian hukum..$^{25}$

Dalam Undang-Undang Nomor 12 Tahun 2011 disebut beberapa bentuk peran serta masyarakat yakni selain rapat dengar pendapat umum dan kunjungan kerja, juga bentuk sosialisasi, seminar, lokakarya, dan/atau diskusi. Keenam bentuk tersebut merupakan bagian dari pertemuan ilmiah yakni ajang komunikasi dua arah antara pembentuk peraturan dengan masyarakat dan hal ini merupakan hal yang esensial dalam kehidupan demokrasi saat ini. Di luar bentuk pertemuan ilmiah tersebut, pada dasarnya masih ada bentuk lain, misalnya simposium, diseminasi, fokus grup diskusi, curah pendapat, studi banding, dan pertemuan ilmiah lainnya. ${ }^{26}$

\section{Pariwisata Halal}

Berwisata merupakan sebuah sarana yang hukumnya berdasarkan tujuannya. Artinya jika tujuannya adalah untuk kewajiban, maka wajib melakukannya, seperti menunaikan haji bagi yang belum pernah menunaikan. ${ }^{27}$ Sejatinya kehadiran pariwisata halal berfungsi untuk mengawal keyakinan para wisatawan agar mereka semakin kokoh dan mantap imannya dengan banyak bertadabbur akan ciptaan Tuhan yang sedemikian kaya dan bervariasi, baik berupa komunitas manusia yang beraneka ragam maupun berupa alam semesta. Hal ini semua, antara lain dapat diperoleh dan dipelajari oleh para wisatawan melalui pariwisata. ${ }^{28}$

24 Ibid., 181.

25 Laporan akhir "Pengkajian Hukum tentang Partisipasi Masyarakat dalam Penentuan Arah Kebijakan Prioritas Penyusunan Peraturan Perundang-Undangan”.....75.

26 Pasal 35 jo pasal 96 Undang-undang Nomor 12 Tahun 2011 tentang Pembentukan Peratura Perundangundangan.

27 Fahad Salim Bahammam, Panduan Wisatawan Muslim, terj. Ganna Pryadarizal Anaedi \& Syifa Annisa (Jakarta: Pustaka Al-Kautsar, 2012), 9

28 Muhammad Djakfar, Pariwisata Halal: Perspektif Multidimensi (Malang: UIN Maliki Press, 2017), 179. 
Ketentuan kriteria destinasi objek wisata yang sesuai dengan syariah atau disebut wisata halal dalam hal ini peneliti mengacu pada fatwa DSN MUI N0.108/ DSN-MUI/X/2016 tentang Pedoman Penyelenggaraan Pariwisata Berdasarkan Prinsip Syariah. Terdapat tiga ranah kewajiban yang harus ditetapkan menurut fatwa tersebut, yakni upaya pencapaian, fasilitas yang wajib dimiliki, dan berbagai upaya yang wajib dihindari. Pertama, wajib dicapai dengan melalui ikhtiar: 1. Mewujudkan kemaslahatan umum; 2. Memperoleh pencerahan, penyegaran, dan penenangan; 3. Memelihara amanah, keamanan, dan kenyamanan; 4. Mewujudkan kebaikan yang bersifat universal dan inklusif; 5. Memelihara kebersihan, kelestarian alam, sanitasi, dan lingkungan; dan 6. Menghormati nilai-nilai sosial-budaya dan kearifan lokal yang tidak melanggar prinsip syariah. ${ }^{29}$

Kedua, berbagai fasilitas yang wajib tersedia, yakni berupa sarana ibadah yang layak pakai, mudah dijangkau dan memenuhi persyaratan syariah. Di samping tersedianya makanan dan minuman halal yang jelas terjamin kehalaannya dengan Sertifikasi Halal MUI. Sebab itu, khusus untuk makanan dan minuman ini, bagaimanapun di tempat wisata perlu tersedia restoran yang melayani konsumsi wisatawan Muslim agar mereka merasa terlayani dan memperoleh kepuasan.

Ketiga, agar wisatawan Muslim tidak terganggu keyakinannya dan tetap turut menjaga muruah-nya sebagai Muslim, hendaknya pada setiap destinasi halal wajib terhindar dari berbagai hal yang menjurus pada kemusyrikan dan khurafat, maksiat, zina, pornografi, pornoaksi, minuman yang memabukkan, narkoba dan judi. Selain juga terhindar dari adanya pertunjukan seni dan budaya serta atraksi yang kontra produksi dengan prinsip-prinsip syariah. ${ }^{30}$

Ketentuan-ketentuan di atas yang nantinya akan digunakan peneliti untuk menganalisa apakah objek wisata yang diteliti sudah sesuai dengan syariah atau belum.

\section{Pemahaman dan Respons Terhadap Terminologi Wisata Syariah}

Untuk memperoleh data dalam penelitian ini, peneliti melakukan wawancara dan menyebar kuesioner kepada stakeholders parwiwsata, antara lain adalah masyarakat pelaku pariwisata, dalam hal ini bisa terdiri dari pengelola objek pariwisata dan para wisatawan serta pemilik industri terkait wisata seperti pemilik hotel dan biro perjalanan. Berikutnya adalah para tokoh masyarakat, yang dalam hal ini adalah para ulama, serta dinas pariwisata.

29 Fatwa Dewan Syariah Nasional Mejelis Ulama Indonesia N0.108/DSN-MUI/X/2016 tentang Pedoman Penyelenggaraan Pariwisata Berdasarkan Prinsip Syariah.

$30 \mathrm{v}$ Ibid. 
Hasil wawancara menunjukkan bahwa penggunaan istilah "wisata syariah" dinilai kurang tepat karena terkesan kaku dan kurang menjual untuk menjadi "branding" pariwisata yang menyasar segmen wisatawan muslim. Penggunaan kata syariah harus sangat hati-hati karena berkaitan dengan pemberlakuan hukum Islam dalam kehidupan sehari-hari. Hal ini berlaku juga dalam praktik bisnis pariwisata.

Apabila bisnis pariwisata yang dijalankan berlandaskan syariah maka harus sungguh- sungguh menegakkan hukum Islam. Hal tersebut disampaikan oleh dinas pariwisata yang telah melakukan FGD dengan para ulama dan pelaku industri pariwisata. Akhirnya pihak dinas lebih cenderung untuk menghindari istilah syariah, halal atau islam. Namun karena memang potensi wisata halal luar biasa, apalagi pada tahun 2019 ini Indonesia menduduki peringkat pertama negara tujuan wisatawan muslim menurut GMTI, akhirnya pihak dinas lebih tertarik untuk mengusung istilah friendly moslem tourism. ${ }^{31}$ Selain istilah itu Dinas pariwista yang lain menggunakan istilah wisata berkearifan lokal. ${ }^{32}$ Hal tersebut dipilih untuk menghindari kesan negatif kata syariah, maksudnya ketika ada kata syariah atau halal atau istilah-istilah islam yang lain dikhawatirkan kalau penerapannya nanti keluar dari nilai-nilai islami. Karena dalam pemahaman banyak tokoh agama wisata itu lebih identik dengan hiburan yang bebas mulai dari pergaulan dan busana. Namun ternyata setelah dilakukan wawancara kepada beberapa ulama, tidak semua ulama berpendapat demikian. Salah satunya ketika wawancara dengan salah satu ulama dari Sampang yang menyatakan sangat mendukung diterapkannya wisata halal. Selain potensi wisata yang banyak dan menarik juga didukung oleh kultur masyarakat islami Madura. ${ }^{33}$ Dari perbedaan pandangan para ulama sebenarnya dapat diketahui beberapa hal, bahwa ulama yang berpandangan bahwa tidak perlu menggunakan istilah-istilah agama berasal dari ulama yang salaf sementara ulama yang moderat tidak mempermasalahkan istilah itu. Untuk mengetahui antara ulama salaf dan moderat dapat dilihat dari lembaga pendidikan yang dikelola oleh para ulama tersebut, kalau dalam lembaganya terdapat pendidikan formal dapat dikategorikan sebagai ulama yang mendukung penggunaan istilah wisata halal. Meskipun begitu pada prinsipnya semua ulama setuju untuk menerapkan pariwisata syariah atau halal, hanya terbentur pada penggunaan istilah saja.

Dinas pariwisata kabupaten Sumenep lebih berperan pasif dalam memberikan informasi wisata islami, maksudnya kalau ada wisatawan resmi luar daerah yang data kedinas pariwisata maka dinas pariwisata memberikan gambaran tentang budaya

31 Wawancara dengan ibu Endah Nursiskawati, Kasi Pariwisata Kabupaten Sampang, pada tanggal 10 Juli 2019

32 Wawancara dengan mantan Kasi pariwisata kabupaten Sumenep pada tanggal 17 Juli 2019.

33 Wawancara dengan KH. Muhammad Muafi, pengasuh PP Nazhatul Thullab Camplong Sampang pada tanggal 11 Juli 2019 
keislaman yang ada di sumenep, seperti harus berpakain rapi ketika berada di tempattempat wisata relegi dan tempat-tempat lain, namun bagi wisatawan backpaker kita tida bisa memantaunya sebab mereka langsung datang ketempat wisata, sehingga kalau ada prilaku yang kurang menyenangkan baru mereka mengadu kepada dinas pariwisata. ${ }^{34}$

\section{Model Partisipasi Masyarakat dalam Penyusunan Peraturan Kepariwisataan (ius constitutum)}

Berdasarkan pengambilan data di lapangan dari keempat model bentuk partisipasi masyarakat: ${ }^{35}$ partisipasi masyarakat dalam penentuan arah kebijakan lebih cenderung kepada dua model yaitu model yang kedua, a basic model of public participation, dan model ketiga, a realism model of publik partisipation. Hal tersebut dapat dilihat dari hasil survei dan wawancara yang dilakukan secara mendalam terhadap beberapa stakeholders di bidang pariwisata. Kecenderungan kepada model yang kedua didasarkan atas adanya keinginan dari masyarakat untuk menerapkan kebijakan pariwisata halal. ${ }^{36}$ Akan tetapi keinginan masyarakat tersebut tidak diakomodir oleh lembaga tertentu untuk kemudian disampaikan kepada pihak pemerintah.

Kecenderungan kepada model yang ketiga dapat dilihat dari adanya Focus Group Discussion yang pernah dilaksanakan oleh keempat dinas pariwisata melalui sekretariat bersama dengan para ulama dan pelaku industri pariwisata. ${ }^{37}$ Lebih tepatnya model partisipasi masyarakat masuk dalam model yang ketiga karena terdapat kelompok pelaku industri di bidang pariwisata dan para ulama yang membahas mengenai pariwisata halal.

Pada dasarnya dalam undang-undang pembentukan peraturan perundangundangan terdapat satu bab yang mengatur mengenai partisipasi masyarakat. Dalam undang-undang tersebut disebutkan bahwa beberapa bentuk peran serta masyarakat yakni selain rapat dengar pendapat umum dan kunjungan kerja, juga bentuk sosialisasi, seminar, lokakarya, dan/atau diskusi. Di luar bentuk pertemuan ilmiah

34 Wawancara dengan mantan Kasi pariwisata kabupaten Sumenep pada tanggal 17 Juli 2019.

35 pertama, partisipasi murni (pure representative democracy) Kedua, a basic model of public participation Ketiga, a realism model of publik partisipation. Keempat, model The Possible Ideal,

$3695 \%$ masyarakat setuju untuk menerapkan wisata halal di Madura berdasarkan kuesioner yang disebar pada bulan Juli, Agustus dan September di empat kabupaten.

37 Wawancara dengan ibu Endah Nursiskawati, Kasi Pariwisata Kabupaten Sampang, pada tanggal 10 Juli 2019. Dilain kesempatan hal senada juga disampaikan oleh mantan Kasi pariwisata kabupaten Sumenep pada tanggal 17 Juli 2019. 
tersebut, pada dasarnya masih ada bentuk lain, misalnya simposium, diseminasi, fokus grup diskusi, curah pendapat, studi banding, dan pertemuan ilmiah lainnya. ${ }^{38}$

Dengan demikian walaupun terdapat ketentuan kepariwisataan provinsi Jawa timur mengeluarkan Peraturan daerah Nomor 6 Tahun 2017 tentang Rencana Induk Pembangunan Kepariwisataan Provinsi Jawa Timur Tahun 2017-2032, yang dalam lampiran Perda tersebut disebutkan bahwa Madura sebagai salah satu destinasi pariwisata provinsi (DPP) Jawa Timur yang mengusung konsep wisata halal dan wisata bahari, ${ }^{39}$ keempat kabupaten di Madura belum bisa menerapkan perda tingkat II yang mengatur tentang pariwisata halal.

Selain itu berdasarkan ketentuan Perda Provinsi Jawa Timur di atas yang mengatur mengenai konsep wisata halal Madura, sudah semestinya daerah-daerah yangberada dipulau Madura membuat peraturan daerah tentang kepariwisataanyang mengusung konsep wisata halal. Sebagaimana hal tersebut di atas bahwa ketentuan mengenai penyusunan atau pembentukan Peraturan Daerah Provinsi berlaku secara mutatis mutandis terhadap penyusunan Peraturan Daerah Kabupaten/Kota. Hal ini sesuai dengan ketentuan pasal 63 yang menegaskan bahwa :

"Ketentuan mengenai penyusunan Peraturan Daerah Provinsi sebagaimana dimaksud dalam Pasal 56 sampai dengan Pasal 62 berlaku secara mutatis mutandis terhadap penyusunan Peraturan Daerah Kabupaten/Kota."

\section{Model Partisipasi Masyarakat Berbasis Nilai Keislaman}

Yang dimaksudkan dengan partisipasi masyarakat di sini adalah keterlibatan individu dalam masyarakat atau organisasi politik dalam pengambilan keputusan atau kebijakan yang terkait dengan kemaslahatan umum baik di tingkat daerah maupun nasional. Secara lebih khusus keterlibatan itu dilakukan oleh politisi muslim, yang diharapkan dari keberadaannya di lembaga-lembaga kenegaraan adalah menyuarakan kebaikan dengan meminimalisir keputusan yang bertentangan dengan ajaran Islam dan memperbesar diberlakukannya keputusan yang memudahkan dakwah Islam berkembang. ${ }^{40}$

Konsep pengambilan keputusan sebagaimana tersebut di atas, dalam sistem perpolitikan Islam menggunakan konsep Shura. Berikut adalah konsep Shura dalam Islam. Kata shura berasal dari kata kerja shawara yushawiru yang berarti menjelaskan, menyatakan atau mengajukan dan mengambil sesuatu. Bentuk-bentuk lain yang

38 Pasal 35 jo pasal 96 Undang-undang Nomor 12 Tahun 2011 tentang Pembentukan Peraturan Perundangundangan.

39 Lampiran II mengenai Peta Perwilayahan Pembangunan Destinasi Wisata dalam Peraturan Daerah Provinsi Jawa Timur Nomor 6 Tahun 2017.

40 Inu Kencana Syafeiie, Ilmu Politik, (Jakarta: Rineka Cipta, 2010) h.242 
berasal dari kata shawara adalah tashawara, artinya berunding, saling bertukar pendapat. shawir, yang artinya meminta pendapat atau musyawarah. ${ }^{41}$ Jadi, shura atau musyawarah adalah saling menjelaskan dan merundingkan atau saling meminta dan menukar pendapat mengenai suatu perkara.

Mayoritas ulama syariat dan pakar undang-undang konstitusional meletakkan musyawarah sebagai kewajiban keislaman dan prinsip konstitusional yang pokok di atas prinsip-prinsip umum dan dasar-dasar baku yang telah ditetapkan oleh nashnash al-Qur'an dan hadis-hadis nabawi. Oleh karena itu, musyawarah sangat lazim digunakan dan tidak ada alasan bagi seorang pun untuk meninggalkannya.

Secara fungsional musyawarah adalah untuk membicarakan kemaslahatan masyarakat dan masalah-masalah masa depan pemerintahan. Dengan musyawarah, rakyat menjadi terdidik dalam mengeluarkan pendapat dan mempraktekkannya, bukan mempraktekkan pendapat seorang kepala negara, sekalipun pendapatnya benar. Karena orang banyak yang bermusyawarah akan jauh dari melakukan kesalahan dari pada diserahkan kepada seseorang yang cenderung membawa bahaya bagi umat. Lebih jauh Abduh menjelaskan bahwa Allah SWT juga mewajibkan kepada para penguasa untuk membentuk lembaga musyawarah, sebab ia merupakan perbuatan terpuji di sisi Allah. ${ }^{42}$ Dalam al- Qur'an, ada dua ayat yang menyebutkan secara jelas mengenai musyawarah, dan setiap satu dari dua ayat tersebut mempunyai petunjuk masing-masing. Dua ayat yang menerangkan tentang musyawarah tersebut antara lain: Al-Qur'an surat Ali-Imran: 159.

Menurut Farid Abdul Khaliq, perintah pada ayat di atas, sekalipun ditujukan kepada Rasulullah SAW, tetapi perintah itu juga ditujukan kepada pemimpin tertinggi negara Islam di setiap masa dan tempat, yakni wajib melakukan musyawarah dengan rakyat dalam segala perkara umum dan menetapkan hak partisipasi politik bagi rakyat di negara muslim sebagai salah satu hak dari hak-hak Allah yang tidak boleh dihilangkan. Pelanggaran penguasa atas hak itu termasuk diantara kemungkaran terbesar, karena begitu besarnya kerusakan dan kemudharatan yang diakibatkan oleh sikap pelanggaran itu terhadap masyarakat dan negara. ${ }^{43}$

Ayat lainnya yaitu Al-Qur'an surat Asy-Syura: 38. Menanggapi ayat ini, Farid Abdul Khaliq berpendapat bahwa ayat di atas mengandung penjelasan tentang sifat rakyat yang baik, dan menyatakan bahwa musyawarah termasuk diantara ciri khas dan keistimewaannya. Jika surat Ali-Imran: 159 menunjukkan bahwa musyawarah adalah sistem hukum dalam Islam, maka surat Asy-Syura: 38 ini menunjukkan

\footnotetext{
41 M. Hasbi Amiruddin, Konsep Negara Islam Menurut Fazlur Rahman,(Yogyakarta: UII Pres) h. 18

42 Menurut Muhammad Abduh sebagaimana dikutip oleh Ichwan Fauzi, Etika Muslim (Wisdom Science Sea,t,t), h.36

43 Farid Abdul Khaliq, Fikih Politik Islam, Diterjemahkan oleh Faturrahman A. Hamid (Jakarta: Amzah, 2005), h. 51
} 
bahwa musyawarah adalah metode hidup. Jadi, kata musyawarah dalam realitanya lebih luas maknanya dari pada kata demokrasi, sebab demokrasi seringkali hanya dalam bentuk parlementer, sedangkan musyawarah adalah metode hidup dalam setiap lembaga pemerintahan, mulai dari penguasa sampai rakyat biasa. ${ }^{44}$

Dari penjelasan di atas, terlihat dengan jelas bahwa musyawarah memiliki kedudukan yang tinggi dalam Islam. Disamping merupakan bentuk perintah dari Allah SWT, musyawarah pada hakikatnya juga dimaksudkan untuk mewujudkan sebuah tatanan masyarakat yang demokratis. Dengan musyawarah, setiap orang yang ikut bermusyawarah akan berusaha mengemukakan pendapat yang baik, sehingga diperoleh pendapat yang dapat menyelesaikan masalah yang dihadapi.

Di sisi lain, pelaksanaan musyawarah juga merupakan bentuk penghargaan kepada tokoh-tokoh dan para pemimpin masyarakat, sehingga mereka dapat berpartisipasi dalam berbagai urusan dan kepentingan bersama. Bahkan pelaksanaan musyawarah juga merupakan bentuk penghargaan kepada hak kebebasan dalam mengemukakan pendapat, hak persamaan, dan hak memperoleh keadilan bagi setiap individu.

Berdasarkan konsep partisipasi masyarakat menurut nilai keislaman di atas, dapat dikemukakan bahwa model partisipasi masyarakat di Madura, dalam hal ini dilakukan dengan Focus Group Discussion, termasuk ke dalam konsep yang sesuai dengan nilai-nilai keislaman. Pelaksanaan FGD merupakan manifestasi dari dari adanya musyawarah sebelum pemerintah daerah, dalam hal ini adalah dinas pariwisata, menetapkan peraturan tentang wisata halal.

\section{Kesimpulan}

Model partisipasi masyarakat dalam hukum positif (ius constitutum) lebih cenderung kepada dua model yaitu model yang kedua, a basic model of public participation, dan model ketiga, a realism model of publik partisipation. Kecenderungan kepada model yang kedua didasarkan atas adanya keinginan dari masyarakat untuk menerapkan kebijakan pariwisata halal. Akan tetapi keinginan masyarakat tersebut tidak diakomodir oleh lembaga tertentu untuk kemudian disampaikan kepada pihak pemerintah. Adapun kecenderungan kepada model yang ketiga dapat dilihat dari adanya Focus Group Discussion yang pernah dilaksanakan oleh keempat dinas pariwisata melalui sekretariat bersama dengan para ulama dan pelaku industri pariwisata. Lebih tepatnya model partisipasi masyarakat masuk dalam model yang

44 Ibid., h. 52 
ketiga karena terdapat kelompok pelaku industri di bidang pariwisata dan para ulama yang membahas mengenai pariwisata halal.

Dalam tinjauan nilai keislaman model partisipasi masyarakat yang ada di Madura sudah sesuai dengan nilai-nilai yang ada dalam sumber hukum Islam yaitu al-Qur'an dan Sunnah, yaitu mempunyai konsep shura. Kuncinya adalah adanya Focus Group Discussion yang pelaksanaannya diwakili oleh unsur-unsur penting dalam masyarakat Madura. Keberadaan FGD sebagai bentuk musyawarah yang harus dilakukan sebelum pemerintah daerah mengeluarkan sebuah kebijakan.

Secara sosiologis, mayoritas masyarakat Madura beragama Islam. Sehingga secara prinsip mereka tidak menolak penerapan wisata halal. Namun di sisi lain para ulama ada yang memandang penggunaan istilah agama seperti syariah, halal atau islami harus benar-benar sesuai dengan prinsip syariah. Mereka masih berpandangan negatif dan tidak yakin apabila wisata disandingkan dengan islam. Para ulama berpandangan seperti itu untuk menjadi keluhuran agama Islam. Meski demikian, Madura tetap menyimpan potensi besar untuk dikembangkan menjadi destinasi wisata syariah atau halal. Pihak dinas pariwisata akhirnya ada yang menggunakan istilah moslem friendly tourism dan wisata berkearifan lokal.

\section{Referensi}

\section{Buku}

Amiruddin, M. Hasbi, Konsep Negara Islam Menurut Fazlur Rahman,(Yogyakarta: UII Pres)

Bahammam, Fahad Salim, Panduan Wisatawan Muslim, terj. Ganna Pryadarizal Anaedi \& Syifa Annisa (Jakarta: Pustaka Al-Kautsar, 2012

Djakfar, Muhammad, Pariwisata Halal: Perspektif Multidimensi (Malang: UIN Maliki Press, 2017

Fauzi, Ichwan, Etika Muslim (Wisdom Science Sea,t,t),

Khaliq, Farid Abdul, Fikih Politik Islam, Diterjemahkan oleh Faturrahman A. Hamid (Jakarta: Amzah, 2005)

Marzuki, Peter Mahmud, Pengantar Ilmu Hukum (Jakarta: Kencana, 2008 -, Penelitian Hukum (Jakarta: Prenada Media, 2005

Rifa'I, Mien A., Manusia Madura: Pembawaan, Perilaku, Etos Kerja, Penampilan dan Pandangan Hidupnya Seperti Dicirakan Pribahasanya (Yogyakarta: Pilar Media, 2007 
Saifuddin, Partisipasi Publik dalam Pembentukan Peraturan Perundang-undangan, (Yogyakarta: FH UII Press, 2009

Sinamora, B., Panduan Riset Perilaku Konsumen (Jakarta: PT Gramedia Pustaka Utama, 2002

Sugiarto, Siagian D, Sunaryanto, L S dan Oetomo, D S., Teknik Sampling (Jakarta: PT Gramedia Pustaka Utama, 2003

Sunggono, Bambang, Metodologi Penelitian Hukum (Jakarta: PT Raja Grafindo Persada, 1998.

Surbakti, Ramlan, Memahami Ilmu Politik (Jakarta: PT. Gramedia Widiasarana Indonesia, 1992

Syafeiie, Inu Kencana, Ilmu Politik, (Jakarta: Rineka Cipta, 2010)

Syahrani, Riduan, Rangkuman Intisari Ilmu Hukum, (Bandung: Penerbit Citra Aditya Bakti, 1999

Tim Redaksi Kamus Besar Bahasa Indonesia Edisi Ketiga, (Jakarta: Balai Pustaka, Departemen Pendidikan Nasional, 2005

Global Muslim Travel Index (GMTI) report 2018

Laporan akhir "Pengkajian Hukum tentang Partisipasi Masyarakat dalam Penentuan Arah Kebijakan Prioritas Penyusunan Peraturan Perundang-Undangan”, oleh Tim Pengkajian Hukum Pusat Penelitian dan Pengembangan Sistem Hukum Nasional Badan Pembinaan Hukum Nasional (BPHN) Kementerian Hukum dan Hak Asasi Manusia RI, 2014,

Fatwa Dewan Syariah Nasional Mejelis Ulama Indonesia N0.108/DSN-MUI/X/2016 tentang Pedoman Penyelenggaraan Pariwisata Berdasarkan Prinsip Syariah.

Peraturan Daerah Provinsi Nusa Tenggara Barat Nomor 2 Tahun 2016 tentang Pariwisata Halal.

Undang-undang Nomor 12 Tahun 2011 tentang Pembentukan Peratura Perundangundangan.

\section{Jurnal dan Prosiding}

Anindya Putra,I Gusti Putu,’Model Pengelolaan Pariwisata Kota Denpasar”, http: / / pasca.unand.ac.id/id/prosiding-seminar-nasional-perencanaan-pembangunaninklusif-desa-kota, Maret 2017. 
D. Hernawan dan G. Pratidina," Model Implementasi Kebijakan Pengembangan dalam Meningkatkan Destinasi Pariwisata di Kabupaten Bogor”, Jurnal Sosial Humaniora, Vol. 6 Nomor 2. Oktober 2015.

Nurhayati, Alfisah, "Revisiting Pariwisata Madura; Studi Kebijakan Pembangunan Kepariwisataan Kabupaten Sampang”, Jurnal Karsa, Vol. XVIII Nomor 2. Oktober 2010.

Rachmad, Teguh Hidayatul," Strategi Branding Wisata Syariah Pulau Madura”, Commed: Jurnal Komunikasi dan Media, Vol. 1 Nomor 2. Februari 2017.

S., Laurensius Arliman,” Peran Investasi dalam Kebijakan Pembangunan Ekonomi Bidang Pariwisata di Provinsi Sumatera Barat”, Kanun: Jurnal Ilmu Hukum, Vol. 20 Nomor 2. Agustus 2018.

Syamsi, Achmad Badarus, "Analisa Potensi Pariwisata di Bangkalan yang sesuai dengan Syariah dalam Menunjang Jawa Timur sebagai Salah Satu Destinasi Pariwisata Syariah", Prosiding seminar nasional dan call papers "Integrasi Disiplin Ilmu Keislaman dalam Konteks Madura”, diselenggarakan oleh Fakultas Keislaman Universitas Trunojoyo pada tahun 2016.

Zunaidi, Arif," Strategi Pemasaran Pariwisata Madura Berbasis Keislaman Menuju Destinasi Pariwisata Berkualitas Berkelanjutan”, Prosiding seminar nasional dan call papers "Pariwisata Berbasis Keislaman dan Kearifan (Tinjauan Hukum, Ekonomi, Budaya dan Pendidikan”, diselenggarakan oleh Fakultas Keislaman Universitas Trunojoyo pada tahun 2017.

\section{Web}

http:/ / disbudpar.bangkalankab.go.id/app/\#, diakses pada tanggal 3 April 2019. https:/ / sampangkab.go.id/, diakses pada tanggal 3 April 2019.

http: / / disparibud.pamekasankab.go.id/index.php/ 78-berita/109-tempat-wisata, diakses pada tanggal 3 April 2019.

http:// sumenepkab.go.id/wisata/baca/alam, diakses pada tanggal 3 April 2019. http://www.disbudpar.ntbprov.go.id/promosi-ntb/, diakses pada tanggal 3 April 2019. 